\title{
SOME ASPECTS OF THE BIOLOGY OF Tilapia zillii (GERVAIS) (PISCES: CICHLIDAE) IN OPA RESERVOIR, ILE-IFE, NIGERIA
}

\author{
O.O. Komolafe \\ Department of Zoology \\ Obafemi Awolowo University \\ Ile-Ife, Nigeria.
}

\begin{abstract}
Some aspects of the biology of Tilapia zillii were examined between October 1997 and February 2000. Fish specimens were collected using a graded set of gillnets and castnets. Out of 1486 fish specimens, 867 were males while 619 were females. Regardless of their sex a significantly high number of fish were caught inshore (69.57\%) than in the offshore areas (30.43\%). In addition $48.65 \%$ of all fish specimens were caught in the middle segment of the reservoir. A wide range of fish sizes were caught and the species was not spatially distributed $\left(\chi_{\text {cal. }}^{2} 27.39<\chi_{\text {tab. }}^{2} 67.51 ;\right.$ df. 820$)$. The species fed on a variety of food substances predominantly shoreline aquatic macrophytes, algae and plankton. The feeding rhythm which started around 6.00am reached a peak by $3.00 \mathrm{pm}$ in the afternoon and it declined gradually until 6.00pm.
\end{abstract}

Keywords: Relative abundance, spatial distribution, stomach content, feeding rhythm, Tilapia zillii.

\section{INTRODUCTION}

African cichlid fishes are widely distributed species in lakes, rivers and even penetrating the smallest water bodies (Reed et al., 1967). Over 200 species of the cichlid family have been reported in inland waters of West Africa (Holden and Reed, 1978). In West African sub-region, various aspects of the biology of $T$. zillii have been reported by Reed et al., (1967), Fryer and Iles (1972), Buddington, (1979) and Trewavas (1983).
Field observations by Lowe-McConnell (1969) showed that $T$. zillii lived in the shallow inshore and surface water bodies. Petr (1967b) reported $T$. zillii in Lake Volta while Arawomo (1987) reported the species in rivers Gurara, Usman and Jabi within the Federal capital territory of Nigeria.

The stomach content of a fish does not reflect consumers' food because some food items are quickly digested (Bagenal, 1978). However, stomach fullness and the percentage of empty stomach are direct evidences for evaluating feeding periodicity 
(Bowman and Bowman, 1980). An understanding of the factors governing fish production is necessary so as to improve production in the West Africa sub-region which is still dependent upon fish imports. This study therefore aims at providing basic information needed for production and proper management of $T$. zillii in the habitat.

\section{MATERIALS AND METHODS}

Opa reservoir is located on the campus of Obafemi Awolowo University, Ile-Ife, Nigeria. With about 116 square kilometres of land as catchment area, the reservoir (Longitudes $4^{\circ} 31^{\prime} \mathrm{E}$ to $4^{\circ} 32^{\prime} \mathrm{E}$ and Latitudes $7^{\circ} 29^{\prime} \mathrm{N}$ to $7^{\circ} 30^{\prime} \mathrm{N}$; Figure 1) has a surface area of about 0.95 square kilometre while the maximum capacity is about 675 cubic metres. The minimum and maximum depths are $0.75 \mathrm{~m}$ and $6.4 \mathrm{~m}$ respectively. The catchment area is characterized by dry (October to March) and rainy (April to September) seasons. The reservoir receives high discharge of water from the catchment area making its water turbid in the rainy seasons.

The substratum of the reservoir is mainly mud and sand with submerged logs of wood. Shoreline vegetation is dense with macrophytes, including
Commelina diffusa Burn, C. erecta Linn, Amarantus hibridus Linn. and Acroceras zizaniodes (Kunth) Dandy some of which eventually decompose during the rainy season. In this study, $T$. zillii specimens were collected using a graded set of gill nets measuring 160 metres long and a width of $3.78 \mathrm{~m}$ with five different mesh sizes of 32 metres each for the distribution study. The mesh sizes were $2.5 \mathrm{~cm}, 5.1 \mathrm{~cm}, 7.6 \mathrm{~cm}, 10.2 \mathrm{~cm}$ and $12.7 \mathrm{~cm}$ respectively. The gillnets were set between $6.00 \mathrm{pm}$ and $7.00 \mathrm{pm}$ in the evenings and left to fish. The fish caught were removed between 6.00am and 7.00am the following morning. The inshore area of the reservoir was the littoral zone where light rays could penetrate to the bottom during dry season while the offshore area was beyond the photic zone. The reservoir was demarcated into three segments on the basis of the depth and distance to the dam wall. Dam area was the area from the dam wall to a distance of about 500 metres into the middle of the reservoir with a depth range of $4.0 \mathrm{~m}$ to $6.4 \mathrm{~m}$ in rainy season. Middle segment was the mid-basin of the reservoir with a depth range of $3.0 \mathrm{~m}$ to $4.5 \mathrm{~m}$ while Upper segment covered the upper reaches of the reservoir with a depth range of $1.5 \mathrm{~m}$ to $3.5 \mathrm{~m}$ (Figure $1)$. These were done so as to carry out equal ran-

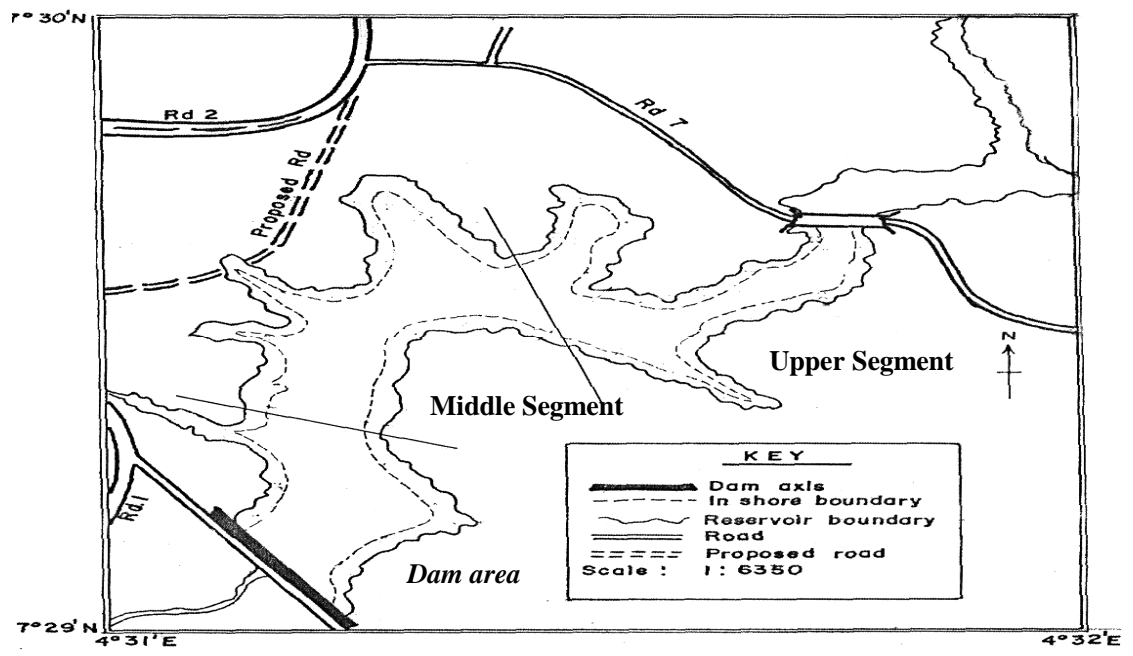

Fig. 1: Opa reservoir showing study site 
dom sampling of fish and to facilitate the description of the actual area where the species was concentrated in the reservoir.

A cast-net of $2.5 \mathrm{~cm}$ mesh size was used to catch various sizes of $T$. zillii. The fishes were transferred to the laboratory where standard morphometric parameters were taken. The content of each fish stomach was weighed to the nearest $0.1 \mathrm{gm}$ and the volume obtained by water displacement in a measuring cylinder. Analyses of the stomach contents of fish specimen were done by frequency of occurrence and numerical methods (Hyslop, 1980; Costa et al., 1992). Food identification was done to genus and species level where possible. Feeding rhythm of $T$. zillii was studied on a three hourly basis starting around 6.00am until the same time the following morning. Stomach fullness of each fish specimen was noted and used to determine feeding rhythm.

\section{RESULTS}

In this study, eleven species of fish were caught. The most abundant fish was Sarotherodon galilaeus followed by Oreochromis niloticus and Tilapia zillii, respectively. These cichlid fishes constituted $99 \%$ of the total catch (Table 1). In the

Table 1: Relative abundance of fish species caught by castnet and gillnet in Opa reservoir

\begin{tabular}{lcc}
\hline \multicolumn{1}{c}{ Fish species } & Number of fish caught & Percentage \\
\hline Sarotherodon galilaeus Linnaeus & 1848 & 37.23 \\
Oreochromis niloticus Linnaeus & 1580 & 31.83 \\
Tilapia zillii Gervais & 1486 & 29.94 \\
Hepsetus odoe Bloch & 26 & 0.52 \\
Mommyrus rume Cuvier and Valenciennes & 4 & 0.08 \\
Hemichromis faciatus Petrs & 3 & 0.06 \\
Hemichromis bimaculatus Gill & 1 & 0.02 \\
Schilble mystus Linnaeus & 8 & 0.16 \\
Heterobranchus bidorsalis Geoffery Saint-Hilaire & 2 & 0.04 \\
Clarias gariepinus (Burchell) & 5 & 0.10 \\
Malapterurus electricus (Gmellin) & 1 & 0.02 \\
Total & $\mathbf{4 9 6 4}$ & $\mathbf{1 0 0}$ \\
\hline
\end{tabular}

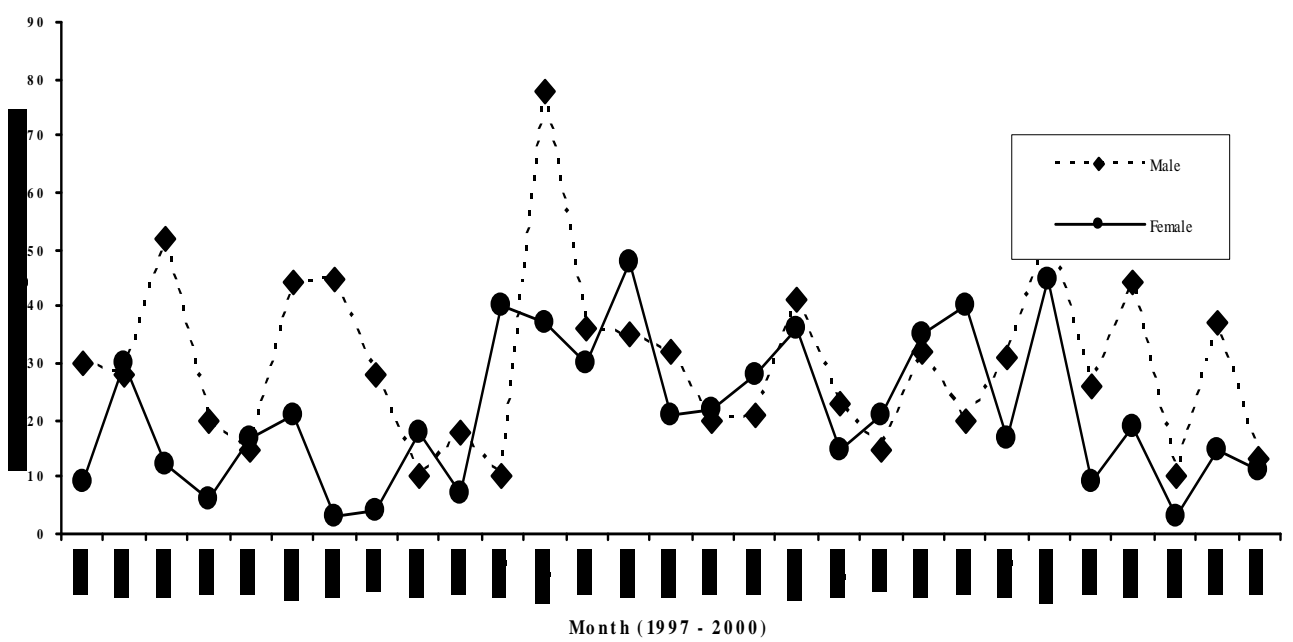

Fig. 2: Relative abundance of fish caught per unit effort on monthly basis 
Table 2: Stomach content analyses of $T$. zillii by number and frequency of occurrence methods in Opa reservoir

\begin{tabular}{|c|c|c|c|c|}
\hline Food items & Frequency of occurrence & Percentage & Number & Percentage \\
\hline \multicolumn{4}{|l|}{ Bluegreen algae } & 1.03 \\
\hline Microcystis sp. & 11 & 4.35 & 301 & 1.61 \\
\hline Oscillatoria sp. & 6 & 2.37 & 116 & 0.62 \\
\hline \multicolumn{5}{|l|}{ Green algae-unicellular } \\
\hline Cosmarium sp & 15 & 5.93 & 308 & 1.65 \\
\hline Pediastrum sp. & 3 & 1.19 & 8 & 0.04 \\
\hline Scenedesmus sp. & 2 & 0.79 & 12 & 0.06 \\
\hline \multicolumn{5}{|l|}{ Green algae-filamentous } \\
\hline Euglena sp. & 8 & 3.16 & 27 & 0.14 \\
\hline Spirogyra sp. & 2 & 0.79 & 5 & 0.03 \\
\hline Ulothrix sp. & 12 & 4.74 & 683 & 3.65 \\
\hline \multicolumn{5}{|l|}{ Green algae-colony } \\
\hline Ankistrodesmus sp. & 29 & 11.46 & 3572 & 19.09 \\
\hline \multicolumn{5}{|l|}{ Diatoms } \\
\hline Melosira sp. & 22 & 8.70 & 2828 & 15.11 \\
\hline Navicula spp. & 19 & 7.51 & 443 & 2.37 \\
\hline \multicolumn{5}{|l|}{ Dinoflagelate } \\
\hline Peridinium sp. & 4 & 1.58 & 138 & 0.74 \\
\hline \multicolumn{5}{|l|}{ Rotifier } \\
\hline \multicolumn{5}{|l|}{ Zooplankton } \\
\hline Copepod sp. & 3 & 1.19 & 7 & 0.04 \\
\hline Phacus sp. & 20 & 7.91 & 394 & 2.11 \\
\hline Ostracod sp. & 2 & 0.79 & 12 & 0.06 \\
\hline Higher plant fragments & 42 & 16.60 & 9419 & 50.34 \\
\hline Insect remains & 4 & 1.59 & 54 & 0.29 \\
\hline Fish scales & 5 & 1.97 & 9 & 0.05 \\
\hline Fish eggs & 19 & 7.51 & 46 & 0.25 \\
\hline Total & 253 & 100 & 18711 & 100 \\
\hline
\end{tabular}

52 Journal of Science and Technology, Vol. 28, No. 1, April 2008 
Table 3: Variation in food consumption in relation to size

\begin{tabular}{|c|c|}
\hline Small fish $(10.00 \mathrm{~cm}-17.9 \mathrm{~cm})$ total length & Big fish $(18.0 \mathrm{~cm}-29.0 \mathrm{~cm})$ total length \\
\hline Microcystis $\mathrm{sp}$ & Microcystis $\mathrm{sp}$ \\
\hline Ankistrodermus sp & Ankistrodermus sp \\
\hline Closterium $\mathrm{sp}$ & Closterium $\mathrm{sp}$ \\
\hline Navicula $\mathrm{sp}$ & Navicula $\mathrm{sp}$ \\
\hline Melosira $\mathrm{sp}$ & Melosira $\mathrm{sp}$ \\
\hline Phacus sp & Phacus sp \\
\hline Anaebena sp & Anaebena sp \\
\hline Cosmarium $\mathrm{sp}$ & Cosmarium $\mathrm{sp}$ \\
\hline Scenedesmus sp & Scenedesmus sp \\
\hline Euglena $\mathrm{sp}$ & Euglena sp \\
\hline Insect remains & Insect remains \\
\hline \multirow[t]{11}{*}{ High plant fragments } & High plant fragments \\
\hline & Copepod sp \\
\hline & Pediastrum $\mathrm{sp}$ \\
\hline & Fish eggs \\
\hline & Oscillatoria $\mathrm{sp}$ \\
\hline & Spirogyra sp \\
\hline & Fish scales \\
\hline & Ulothrix sp \\
\hline & Peridinium $\mathrm{sp}$ \\
\hline & Branchionus sp \\
\hline & Ostracod sp. \\
\hline
\end{tabular}

reservoir while $48.65 \%$ and $31.08 \%$ in the middle and dam area of the reservoir, respectively. This is similar to the distribution of Oreochromis niloticus in the same habitat where $30.57 \%$, $41.78 \%$ and $27.65 \%$ of fish specimens were caught in upper segment, the middle and dam area of the reservoir, respectively (Komolafe and Arawomo, 2003). Fish specimens totalling 68.7\% of the total catch were caught from the inshore area of Opa reservoir. This observation was also reported by Ita (1978) where $77.8 \%$ of $T$. zillii were caught at the inshore area of Lake Kainji. Petr (1967b) also reported a high concentration of
T. zillii in the shallow inshore area of Volta lake. Inshore concentration of the cichlid fishes had been associated to the presence of breeding adults (Gwahaba, 1975). The concentration of T. zillii at the inshore area of Opa reservoir might be attributed to availability of the marginal aquatic macrophytes which form the main bulk of their food. This is in agreement with Arawomo (1982) for Distichodus sp. in Lake Kainji where the distribution was governed by the presence of emergent grasses and sedges in the shallow inshore area of the lake. 
Natural food materials such as aquatic macrophytes and algae found in the stomach of $T$. zillii were similar to that of Abayomi (1986) and Komolafe and Arawomo (2003) on S. galilaeus and 0. niloticus in Opa reservoir respectively. Petr (1967a) in lake Volta and Akintunde and Imevbore (1979) in lake Kainji similarly reported that $T$ zillii fed on aquatic macrophytes. Although there was an evidence of some selectivity on the plankton which the species ingested upon in Opa reservoir, aquatic macrophyte, which the fish mostly ingested have been reported by Buddington (1979) and Trewavas (1983) as food of cichlid fishes in West African water bodies. The species utilised the abundance of food in the habitat to its advantage. About $83 \%$ of all fish specimens fed during the day and the peak was between 12.00 noon and 3.00pm (Figure 3). This was also the observation of Fawole (1996) and Komolafe and Arawomo (2003) in the same habitat were they reported the peak feeding periods between 12.00 noon and $3.00 \mathrm{pm}$ for $O$. niloticus and $S$. galilaeus.

\section{CONCLUSION}

In every part of Opa reservoir were found T.zillii specimens during the period of study. About $49 \%$ of the fish were caught in middle segment showing that $T$. zillii was not spatially distributed in the reservoir where the fish ranked third in abundance. T. zillii was observed to feed during the day with a peak and 12.00 noon and $3.00 \mathrm{pm}$. A lot of natural food materials on which $T$. zillii selectively fed upon also supported its population in the habitat. The concentration of a large number of the specimens $(70 \%)$ at the reservoir shoreline might also help to prevent a dense weed cover.

\section{ACKNOWLEDGEMENT}

The author thanks the Opa Dam Authority of the Obafemi Awolowo University, Ile-Ife, for granting the permission to carry out the research in Opa Reservoir 


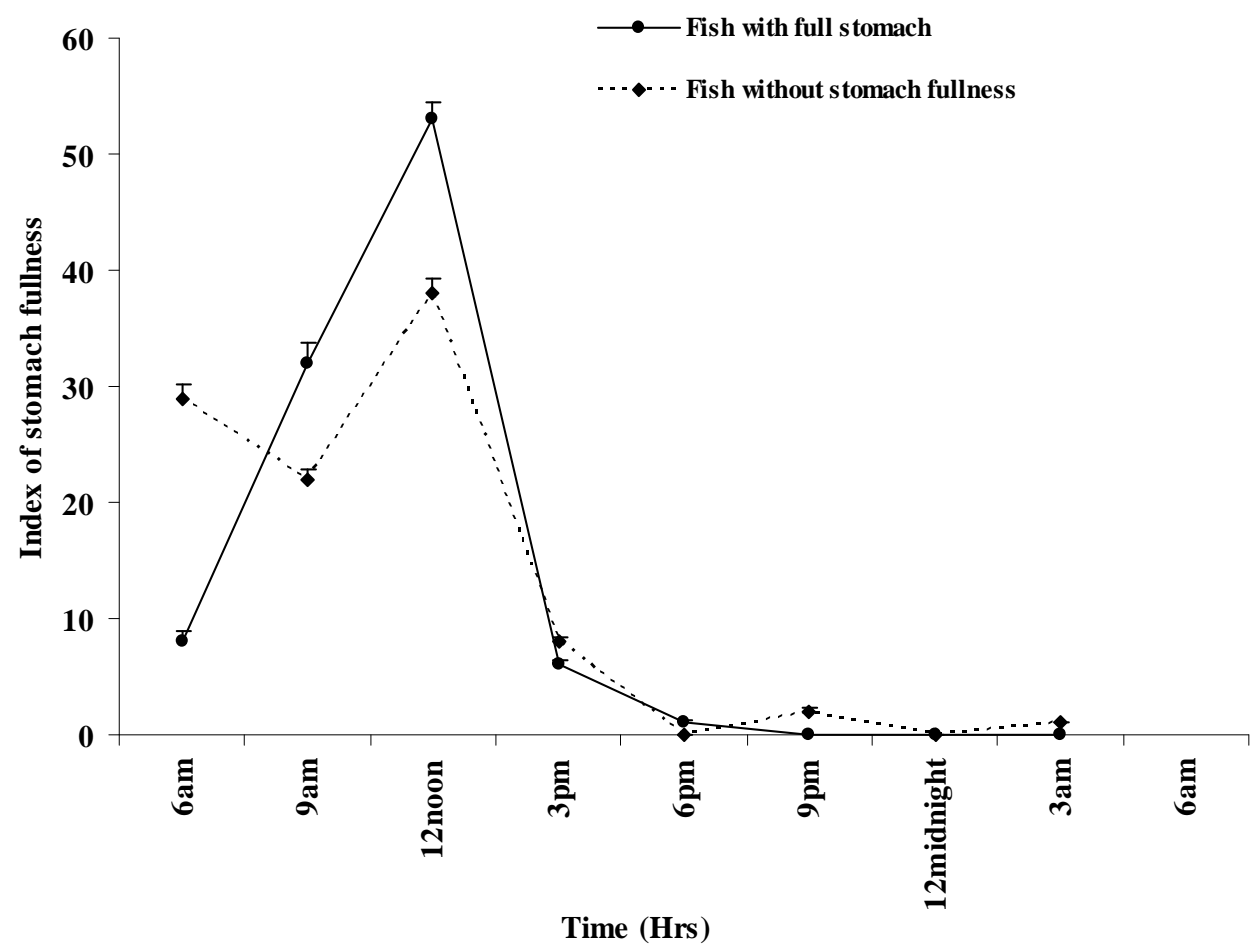

Figure 3: Feeding rhythm of $T$. zillii (Number of replicates =8)

\section{REFERENCES}

Abayomi, O.S. (1986). The distribution, food and feeding habits of Sarotherodon galilaeus in Opa reservoir, University of Ife, Ile-Ife, Nigeria. Unpublished M.Sc. dissertation of the University of Ife, Ile-Ife, Nigeria.

Akintunde, E.A and Imevbore, A.M.A. (1979). Aspects of the biology of the cichlid fishes of Lake Kainji, with special reference to Sarotherodon galilaeus. Nig. J. Nat. Sci. 1 (i): 35-39.

Arawomo, G.A.O. (1982). Food and feeding of three Distichodus species (Pisces: Characifomes) in Lake Kainji, Nigeria. Hydrobiologia, 94: 177-181.
Arawomo, G.A.O. (1987). The fish fauna of the rivers in the new Federal capital territory, Abuja, Nigeria, Ife Journal of Science. 2(1 \& 2): 37-43.

Bagenal, J.B. (1978). Methods for assessment of fish production in freshwaters.

Blackwell Scientific Publications. Oxford. 365pp.

Bowman, R.E. and Bowman, E.W. (1980). Diurnal variation in the feeding intensity and catchability of Silver Hake (Merluccius bilinearis) Can. J. Fish. Aquat. Sc. 37: 1565-1572.

Buddington, R.K. (1979). Digestion of an aquatic macrophyte by Tilapia zillii. J. Fish. Biol. 15 (4): 449-455. 
Costa, J.L., Assis, C.A., Almeida, P.R., Moreira, F.M. and Costa, M.J. (1992). On the food of the European eel Anguilla anguilla (L): in the upper zone of the Tages estuary, Portugal. J. Fish. Biol. 41: 841-850.

Fawole, O.O. (1996). Some aspects of the population dynamics of Sarotherodon galileaus (Artedi) in Opa reservoir, Ile-Ife, Nigeria. Unpublished Ph.D. thesis of Obafemi Awolowo University, Ile-Ife, Nigeria.

Fryer, G. and Iles, T.D. (1972). The cichlid fishes of the Great Lakes of Africa. Oliver and Boyd. Edinburgh. 641pp.

Gwahaba, J. J. (1975). The distribution, population density and biomass of fish in an equatorial lake, Lake George, Uganda. Proc. $R$. Soc. Lond B. 190: 393- 414.

Holden, M.J. and Reed, W. (1978). West African freshwater fish. (West African nature handbooks). Longman Group Ltd., Lond. 88pp.

Hyslop, E.J. (1990). Stomach content analyses A review of methods and their application. $J$. Fish. Biol. 17: 411 - 429.

Ita, E.O. (1978). An analysis of fish distribution in Kainji lake, Nigeria. Hydrobiologia 58(3): 233-244.

Komolafe, O.O. and Arawomo, G.A.O. (2003). The distribution and feeding habits of a cichlid fish Orechromis niloticus Linnaeus in Opa reservoir, Ile-Ife, Nigeria. Bioscience Research Communication 5(5): 479-386.
Lowe-McConnell, R.H. (1969). The cichlid fishes of Guyana, South America, with notes on their ecology and breeding behaviour. Zool. F. Linn. Soc. 48: 255-302.

Pearcy, W.G. and Jullie, W.A. (1974). Food habits of deep sea macrourid fishes off the Oregon Coast. Deep. Sea. Res. Oceanogr. Abstr. 21 (a): 745-759.

Petr, T. (1967a). Food preferences of the commercial fishes of the Volta Lake. University of Ghana Volta Basin research project, Technical report. X22.

Petr, T. (1967b). Fish population changes in the Volta Lake in Ghana during its first sixteen months. Hydrobiologia 30: 193-220.

Reed, W., Burchar, J., Hopson, A.J., Jenness, J. and Ibrahim, Y. (1967). Fish and Fisheries of Northern Nigeria. Published by Ministry of Agriculture, Northern Nigeria. Gaskiya Corp. Zaria. 226pp.

Trewavas, E. (1983). Tilapiine fishes of the genera Sarotherodon, Oreochromis and Danakilia. The Dorset Press. Dorchester. British Museum (Natural History). 583pp. 